\title{
Management of the Fontan circulation in the adult patient
}

\section{Paul Clift}

University Hospital Birmingham NHS Foundation Trust, Queen Elizabeth Hospital, Edgbaston, Birmingham, United Kingdom

Address for correspondence:

Dr Paul Clift

University Hospital Birmingham NHS Foundation Trust

Queen Elizabeth Hospital

Edgbaston

Birmingham

BI5 2TH

United Kingdom

Email: paul.clift@uhb.nhs.uk; pclift@doctors.org.uk

\section{BACKGROUND}

The Fontan circulation is a palliative surgical procedure first described nearly 40 years ago for the management of patients with a univentricular circulation. Over the years the operation has undergone a number of modifications from the one described by Francis Fontan, each leading to improvements in the patient's wellbeing and survival. A child born today with a univentricular circulation in a country with a developed paediatric surgical programme is likely to survive to adult life with relatively few problems. This paper will describe the concept of the univentricular circulation in detail, the operation described by Francis Fontan and its various subsequent modifications and how these patients are managed in adult life. There is little evidence base to the management of these patients and the various complex scenarios they face, and the views expressed here are based largely on the experience of managing these patients over many years in a specialised adult congenital heart disease $(\mathrm{ACHD})$ unit.

\section{UNIVENTRICULAR HEART}

The term "univentricular circulation" refers to a congenital heart defect in which a biventricular repair is not possible. This typically occurs in situations where there is hypoplasia of one of the ventricles, but can occur rarely in situations where two well-formed ventricles are present, but a biventricular repair is not possible due to other anatomical considerations. In all its various forms the

\section{ABSTRACT}

The Fontan circulation poses challenges for the patient and clinician throughout the patient's lifetime. Given the unique physiology of the Fontan circulation, even the best Fontan patient will have a degree of exercise limitation and, with advancing years, the life threatening complications of the condition become more common. Key to the preservation of life and minimising the effects of these complications is prompt recognition and management. Patients with this complex condition require lifelong follow up in specialised units, where all members of the multidisciplinary team are experienced in managing the patients. The provision of this level of care requires planning, and in all healthcare systems where these patients are, care should be taken to develop a system of adult congenital heart disease units to facilitate the management of these and other complex cardiac conditions. This review summarises the anatomy and physiology of the Fontan circulation and provides guidance on the follow up of these patients and the complications they present with. SAHeart 20I3;10:600-615

univentricular heart is thankfully rare but the impact on survival is severe.

\section{PRESENTATION OF UNIVENTRICULAR CIRCULATION}

A univentricular heart will typically present in the neonatal period with variable cyanosis and failure to thrive. Increasingly, screening of the fetus in utero is allowing pre-natal diagnosis of a univentricular heart. The management of prenatally diagnosed cases varies between healthcare systems and therefore the burden of patients with Fontan circulations on ACHD services will vary between countries and needs to be taken into consideration in planning ACHD service development

\section{TYPES OF UNIVENTRICULAR HEART}

There are many possible univentricular hearts and a number of classification schemes have been described. From an ACHD perspective it is useful to consider a few anatomical characteristics: atrial arrangement, atrioventricular valve morphology and ventricular morphology (Figure Ia, Ib, Ic), as all of these features will 
contribute to problems that may be faced in adult life, as will be discussed later.

\section{VENTRICULAR MORPHOLOGY AND OUTCOME}

Whilst the perception is that a single morphological left ventricle will have a better prognosis than a single right ventricle, other anatomical considerations play a greater role in the long term outcomes of patients with a univentricular circulation. The approach to Fontan palliation for patients with tricuspid atresia or double inlet right or left ventricle is largely similar with a staged approach culminating in a total cavopulmonary connection. However isomeric hearts will have abnormalities of pulmonary and systemic venous returns that require special consideration. Similarly the hypoplastic left ventricle will require complex immediate palliation in the neonatal period which is associated with a high early mortality. These factors pass into adult life and palliated patients with isomeric circulations and hypoplastic left heart syndrome will have greater degrees of effort intolerance, a greater arrhythmia burden and will be more difficult to manage owing to the complexities of their condition.

\section{SURVIVAL BEFORE FONTAN PALLIATION}

The case for the Fontan circulation is easily made when considering survival statistics for patients with a univentricular circulation. The vast majority of patients with an unpalliated single left ventricular circulation will die before reaching adult life and survival is even worse with a single right ventricular circulation with survival above 5 years unlikely and worse still with the hypoplastic left heart syndrome (HLHS) where unoperated survival beyond one week is rare. Therefore the case for surgery to improve survival is easily made, and the Fontan operation in its various forms does deliver survival benefit, with survival to adult life to be expected in even the most complex forms of a univentricular heart. However, the Fontan circulation comes at a cost, with significant morbidity in childhood and increasing into adult life. There are also limitations to cardiopulmonary performance which are inherent in the Fontan circulation and will be discussed in detail below.

\section{FONTAN ORIGINAL PAPER}

In 1971, Francis Fontan published the first surgical paper outlining a palliative surgical procedure for patients with tricuspid atresia. ${ }^{(1)}$ The paper describes in detail the formation of a valved conduit placed between the right atrium and the main pulmonary artery (MPA) with the formation of a classical Glenn connection between the superior vena cava (SVC) and the right pulmonary artery (RPA). It became apparent early on that the valved conduit placed an unacceptably high resistance to pulmonary blood flow and this pro-

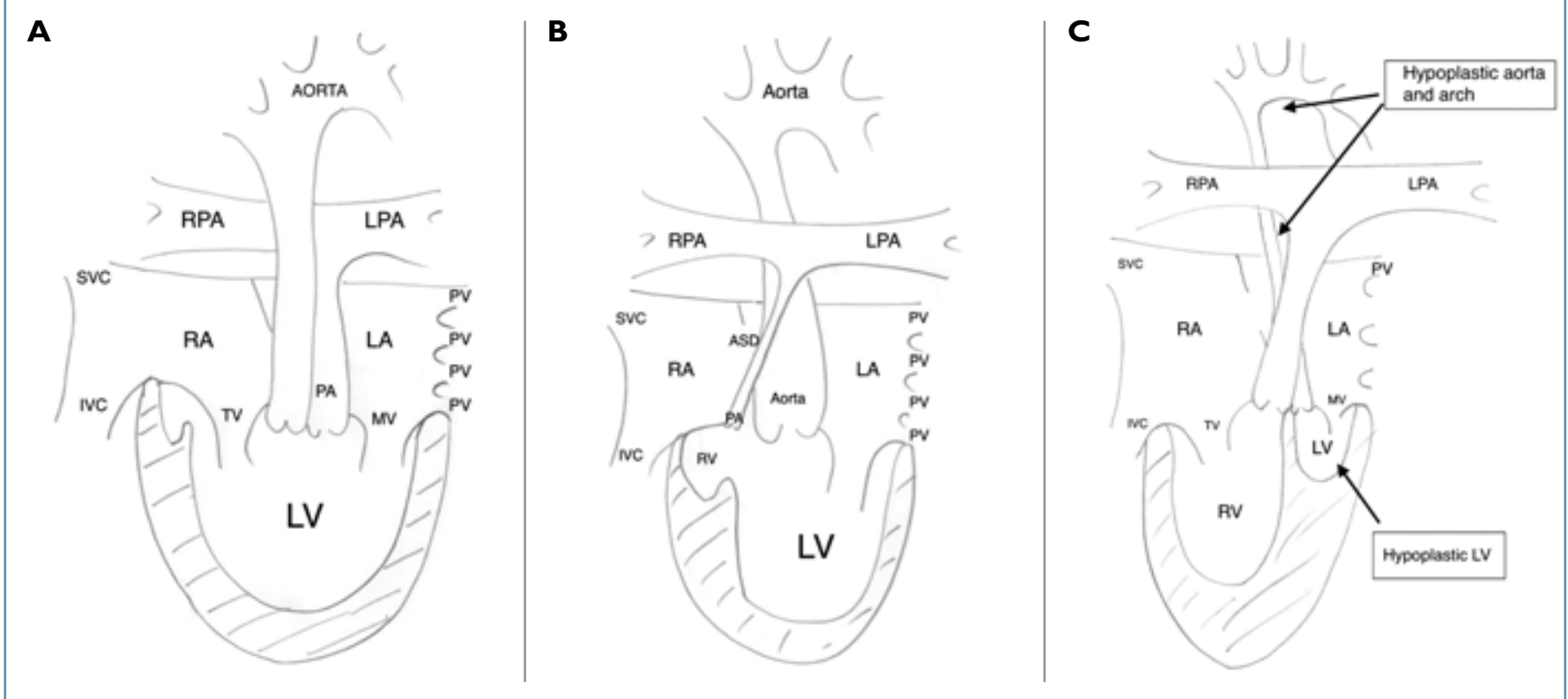

FIGURE I: Anatomical variations on a univentricular circulation.

A: Double inlet left ventricle with VA discordance and no pulmonary stenosis.

B: Tricuspid atresia with hypoplastic RV, VA concordance and hypoplastic pulmonary artery.

C: Hypoplastic left heart syndrome with AV and VA concordance, hypoplastic left ventricle, aorta and aortic arch. 
cedure was altered to allow a direct connection of the right atrium to the main pulmonary artery, initially in combination with a classical Glenn operation, subsequently the connection was widened to allow flow into both pulmonary arteries and the SVC remained connected to the RA. This operation became the standard Fontan operation for many years and is referred to as a modified Fontan or an atriopulmonary (AP) Fontan operation. ${ }^{(2)}$

\section{FONTAN'S TEN COMMANDMENTS}

Follow up of Fontan's early series of cases, allowed the team to establish key selection criteria that would predict a favourable outcome from surgery which have been refined to be age above four years, normal ventricular function, adequate pulmonary artery size, no distortion of pulmonary arteries from prior shunt surgery, low pulmonary artery pressure (below $15 \mathrm{mmHg}$ ), low pulmonary vascular resistance, normal systemic venous drainage, no atrioventricular valve leak, normal heart rhythm and no right atrial enlargement.(3) Follow up of patients meeting these criteria by Fontan's group demonstrated an early mortality during the 6 months following surgery that stabilised with good early survival but a steady decline from 6 years following surgery onwards. Survival rates being $92 \%, 89 \%, 88 \%, 86 \%, 81 \%$, and $73 \%$ at I month, 6 months, and I, 5, 10, and 15 years following surgery. ${ }^{(4)}$ Follow up of our own series showed improved survival of $90 \%, 86 \%$ and $82 \%$ at 5,10 and 15 years, with multivariate analysis showing that pre-operative impaired ventricular function, elevated pulmonary artery pressures and early year of operation were the only predictors of early and late mortality following Fontan surgery whilst right atrial isomerism and small pulmonary arteries were predictors of reintervention. (5) Ventricular morphology did not predict early or late mortality in our series, however predictors of very long term survival (>20 years) remain to be established. This has lead our unit to consider ventricular function and pre-Fontan pulmonary artery pressures as the key points to consider whether Fontan palliation is a viable option.

\section{MODIFICATIONSTO THE FONTAN CIRCULATION}

Whilst the AP Fontan was successful in providing long term survival and reduction in cyanosis, it is an inherently an inefficient circulation. The RA dilates with time and becomes a capacitance chamber into which the SVC and IVC flow return, the forward flow into the lungs becomes turbulent and of low velocity and becomes more dependent with time on inspiration and diastolic relaxation of the ventricle for transpulmonary blood flow. This is due to the reducing effect of atrial contraction as the RA dilates.
The fundamentals of fluid mechanics need to be understood at this point: in a closed circuit turbulent flow leads to energy loss and an increase in power requirements. As the RA dilates with age the circulation becomes more inefficient and this places a greater stress on the single ventricle. Furthermore, in normal biventricular circulations, the pulmonary and systemic circulations are synchronised and each have a pump to work against the resistances. In the palliated univentricular circulation, the systemic circulation is pulsatile and the pulmonary circulation is not, the circulations run in series and the non-pulsatile pulmonary circulation causes a large reflective wave of resistance leading to an increased afterload. ${ }^{(6)}$ In order to overcome this afterload the single ventricle hypertrophies. The hypertrophied ventricle requires an increased pre-load to maintain the cardiac output and yet the Fontan patient has no means of increasing trans-pulmonary blood flow, beyond a modest increase in heart rate and an increase in respiratory rate.

\section{DEVELOPMENT OF THE TOTAL CAVOPULMONARY CONNECTION (TCPC)}

In order to address the issues of inefficiency in the Fontan circuit, Marc de Leval and colleagues developed the concept of a total cavopulmonary connection. ${ }^{(7)}$ Using computational mathematical modeling techniques they demonstrated that by surgical creation of a tube to connect the IVC directly to the PA and by using a bidirectional Glenn, they could reduce power losses in the circuit and eventually by angling the connection of the IVC tunnel away from the SVC flow into the PA they optimised efficiency and minimised power losses. This tunnel can be achieved by two methods, which are routinely used in congenital surgical practice today: the lateral tunnel, created by the septation of the right atrium by means of a GoreTex patch ${ }^{(8)}$ or by an extracardiac GoreTex tube, connecting the IVC to the PA. ${ }^{(9)}$ This type of Fontan is often referred to as a "total cavopulmonary connection" or TCPCFontan (Figure 2). As previously discussed, this has the benefit of maximising trans-pulmonary blood flow, maintaining efficient laminar blood flow through the circuit, reducing the overall systemic vascular resistance which ameliorates ventricular hypertrophy, increasing transpulmonary blood flow and therefore recruits preload to the single ventricle. This improves resting and exercise haemodynamics. In patients in whom there may be concerns about post operative haemodynamics, a fenestration in the lateral tunnel or conduit can be made into the pulmonary venous atrial compartment, which will augment pre-load at the cost of mild cyanosis. ${ }^{(10)}$ 

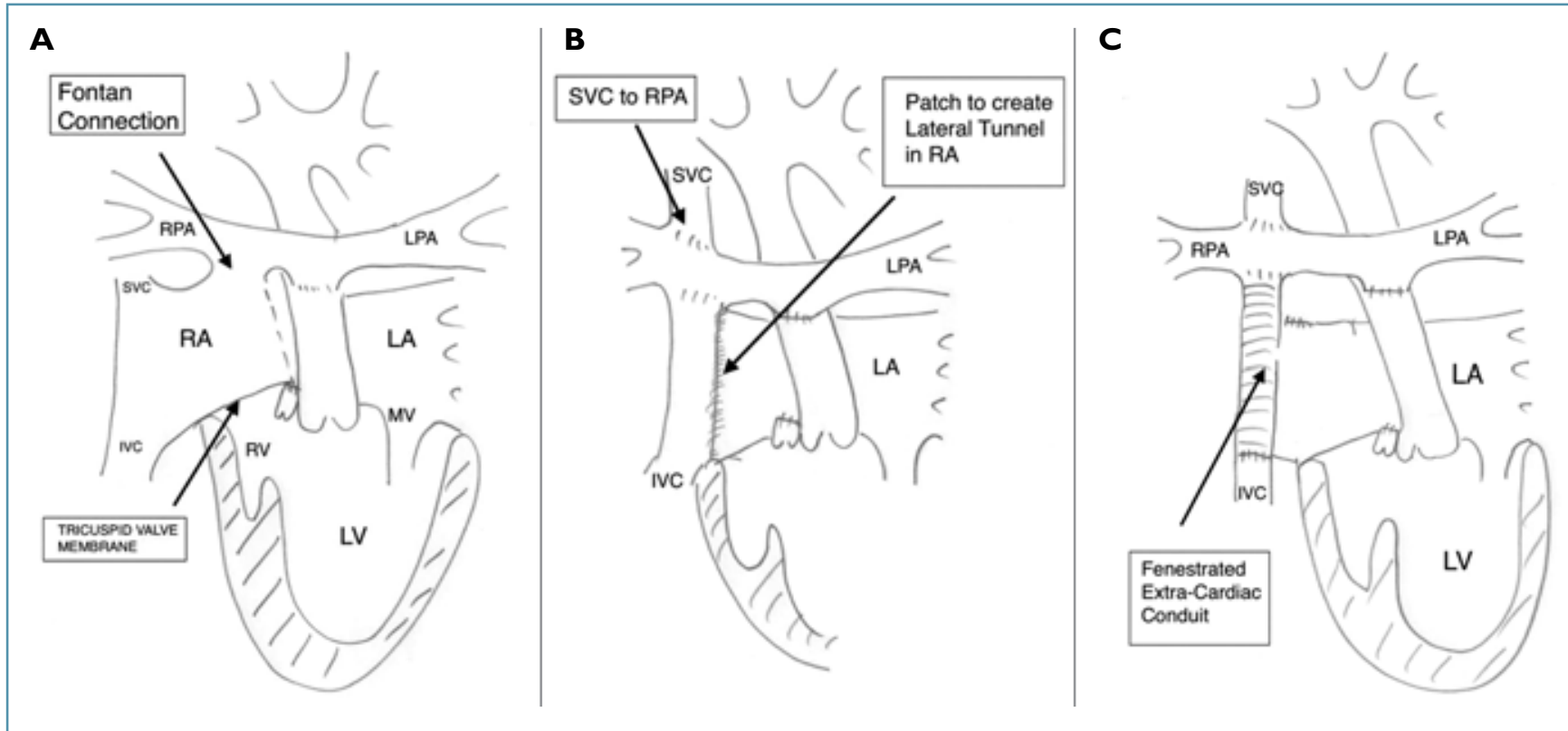

FIGURE 2: The Fontan operation and its modifications.

A: Modified atriopulmonary Fontan with direct connection between the right atrium and pulmonary artery.

B: Lateral Tunnel Fontan, a type of total cavopulmonary connection Fontan, with septation of the atrium by a GoreTex patch to connect the IVC to the PA with a bidirectional Glenn.

C: An extracardiac Fontan, a type of total cavopulmonary connection Fontan, with a GoreTex tube connecting the IVC to the PA.

In 1981 Bill Norwood published the outcomes of his initial operations for palliation of the hypoplastic left heart syndrome (HLHS). ${ }^{(11)}$ This condition is associated with almost universal mortality in the neonatal period, and Norwood utilised the formation of a side by side anastomosis of the main pulmonary artery and the hypoplastic aorta, with arch reconstruction, the so called Damus-Kaye-Stansel connection to create a unified outflow from the right ventricle. ${ }^{(12)}$ This allows for completion of a Fontan palliation using a 3 stage approach (Figure 3).

For a full review of the management of the HLHS and the outcomes of the Norwood procedure and the hybird approach to the stage I procedure (Figure 4) see our groups review. ${ }^{(13)}$

Our understanding of the specific physiological considerations of the Fontan circulation in the context of HLHS remains poor, however, the formation of a reconstructed ascending aorta and arch and the effects of this on aortic compliance and systemic vascular resistance remain a concern. How the RV will cope in this particular circulation remains to be established in the long run and concerns remain regarding coronary blood flow off the hypoplastic ascending aorta. All of these factors are likely to be detrimental to the long term systemic right ventricular function, in addition to the adverse haemodynamics of the Fontan circulation.

\section{HAEMODYNAMIC CONSEQUENCES OF FONTAN CIRCULATION}

The Fontan circulation in all its forms raises a challenge to our fundamental understanding of the circulation. Marc de Leval, discusses this at length in his review of 2005.(14) In short, the Fontan circulation is an alternative physiology to that described by Harvey and the long term management of the Fontan patient is dependent on a full understanding of this physiology. The cardiac output is dependent on adequate pre-load of the single ventricle, which in itself is dependent on a low pulmonary vascular resistance, maintenance of sinus rhythm and systemic venous hypertension. This is demonstrated in Figure 5, where pressure in the various stages of the circulation is shown in the resting state and on exercise in a normal subject and in a Fontan patient. ${ }^{(15)}$ In a normal subject cardiac output is increased by pre-load recruitment with the effect of the muscular venous pump, being to increase RV pre-load, and increased heart rate and force of contraction pushing blood through the pulmonary vascular bed, leading to increased pre-load to the left ventricle and a consequent increase in stroke volume, which coupled with increased heart rate leads to an increase in cardiac output. In comparison, the lack of a sub-pulmonary pump and preexistent systemic venous hypertension, a requirement of the Fontan circulation, means that during exercise there is little pre-load 

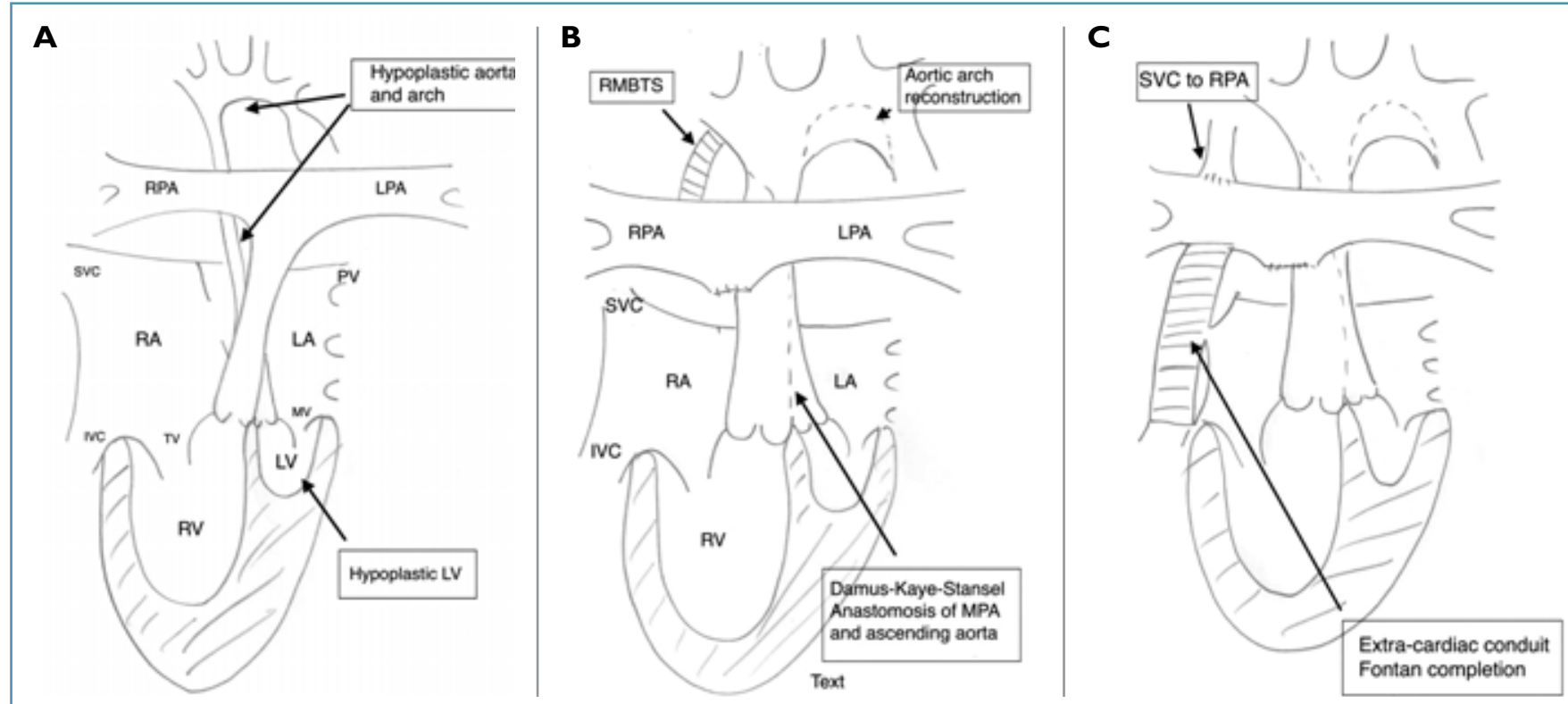

FIGURE 3: The staged palliation of hypoplastic left heart syndrome (HLHS).

A: Norwood stage I. Formation of the Damus-Kaye-Stansel (DKS), anastomosis of the ascending aorta and main pulmonary artery creating a single outflow. Maintenance of pulmonary blood flow via a modified Blalock-Taussig shunt (MBTS). Aortic arch reconstruction.

B: Norwood stage 2. Formation of a bidirectional Glenn (SVC to PA) and takedown of MBTS.

C: Norwood stage 3. Completion of TCPC Fontan with extracardiac conduit.

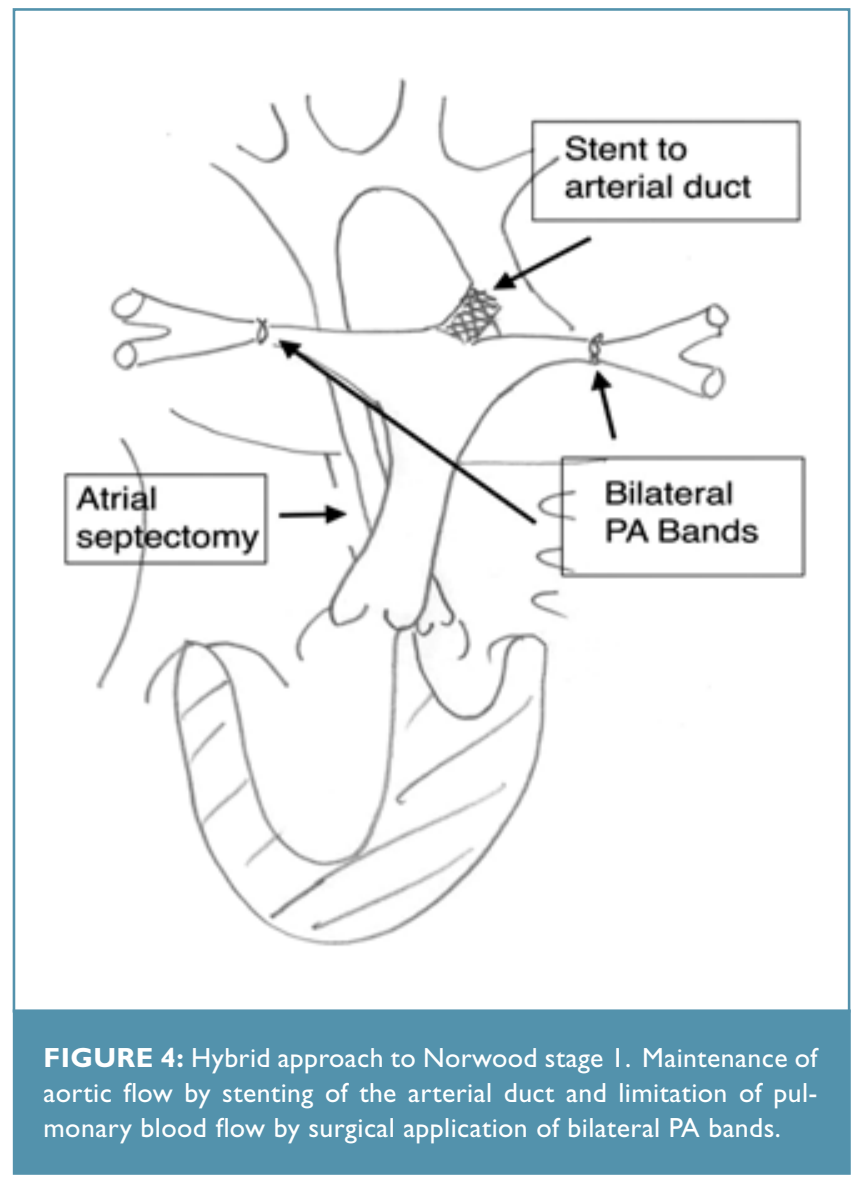

recruitment and increases in cardiac output are determined by heart rate, but within a narrow range, as diastolic filling time becomes increasingly important to maintenance of pre-load. Thus, the Fontan patient is unable to increase cardiac output to the extent that a biventricular circulation can (Figure 5).(16) There is therefore a built in limitation and fragility to the Fontan physiology, which becomes important when considering the late complications that patients may face.

\section{EXERCISE LIMITATION}

Objective cardiopulmonary exercise testing is limited in the Fontan patient, when even the "asymptomatic" Fontan patient will have a reduction in the measured peak $\mathrm{VO}_{2}$, typically in our experience around $70 \%$ of the predicted value and this is consistent across the different ventricular morphologies and anatomies, except the HLHS patients who on average have a lower peak $\mathrm{VO}_{2}$ ( $62 \%$ of predicted). Further studies in adult Fontan patients are required to determine which groups, if any, have an adverse outcome with regards to exercise performance.

\section{FOLLOW UP OF ADULT FONTAN PATIENTS}

Our standard approach to managing any adult with complex congenital heart disease starts in the teenage years, through the process 
of transition. There is no absolute age at which transitional care starts, it clearly depends on individual patients' circumstances, although we aim to have started the process by the age of 14 if possible. Our approach is for a specialist transitional care nurse to meet with the patient and family in the paediatric clinic and start to develop a relationship. We discuss the diagnosis and the operations they have undergone and what impact, if any, this has had on them as individuals. We start the discussion regarding pregnancy and contraception whilst also counseling the patient against the use of recreational drugs and cigarette smoking. We discuss alcohol consumption and other lifestyle issues such as piercing and tattoos and the need for regular dental follow up. This is a process that occurs over a number of clinic visits and culminates in their transfer to adult services between the ages of 16 and 18 years.

Advice is also given regarding career options. Currently the UK armed forces will not accept recruits with any history of congenital heart disease. We also discuss appropriate sporting and other leisure activities, including whether they can scuba dive.

At their first visit we cover the same points raised in transition clinics, perform a routine cardiovascular examination and the following routine examinations: 12 Lead ECG, transthoracic echocardiogram, 24 hour ECG monitoring, cardiopulmonary exercise and cardiac MRI imaging in those in whom it is possible. This provides us with our baseline haemodynamic assessment, which we will compare future results with.

It is our standard practice to provide patients with a laminated copy of their 12 ECG for them to have with them in case they are ever reviewed in an emergency department with palpitations. Patients are also copied in to all correspondence so they have their own health care records. All patients are given contact details for the unit, the hospital and our clinical nurse specialists. Follow up is every 12 months or at short notice if a situation arises.

\section{Medications}

The non-pulsatile and often turbulent blood flow through the Fontan, predisposes the patient to thromboembolism, ${ }^{(17)}$ which can have dire consequences. Even micro thrombi in the Fontan pathway can, in time, lead to an increase in the pulmonary vascular resistance and large thrombi can occlude the circuit with fatal consequences. ${ }^{(18,19)}$ In addition many patients have a right to left shunt and the risk of a paradoxical embolus is present. For these reasons we routinely anticoagulate our patients with Warfarin with a target INR of 2 to 2.5. Many centres advocate aspirin alone ${ }^{(20,21)}$ and although no reports demonstrate superiority, (22) it is clear that either is necessary and without antiplatelet or anticoagulant therapy thromboembolic events are frequent. ${ }^{(23)}$

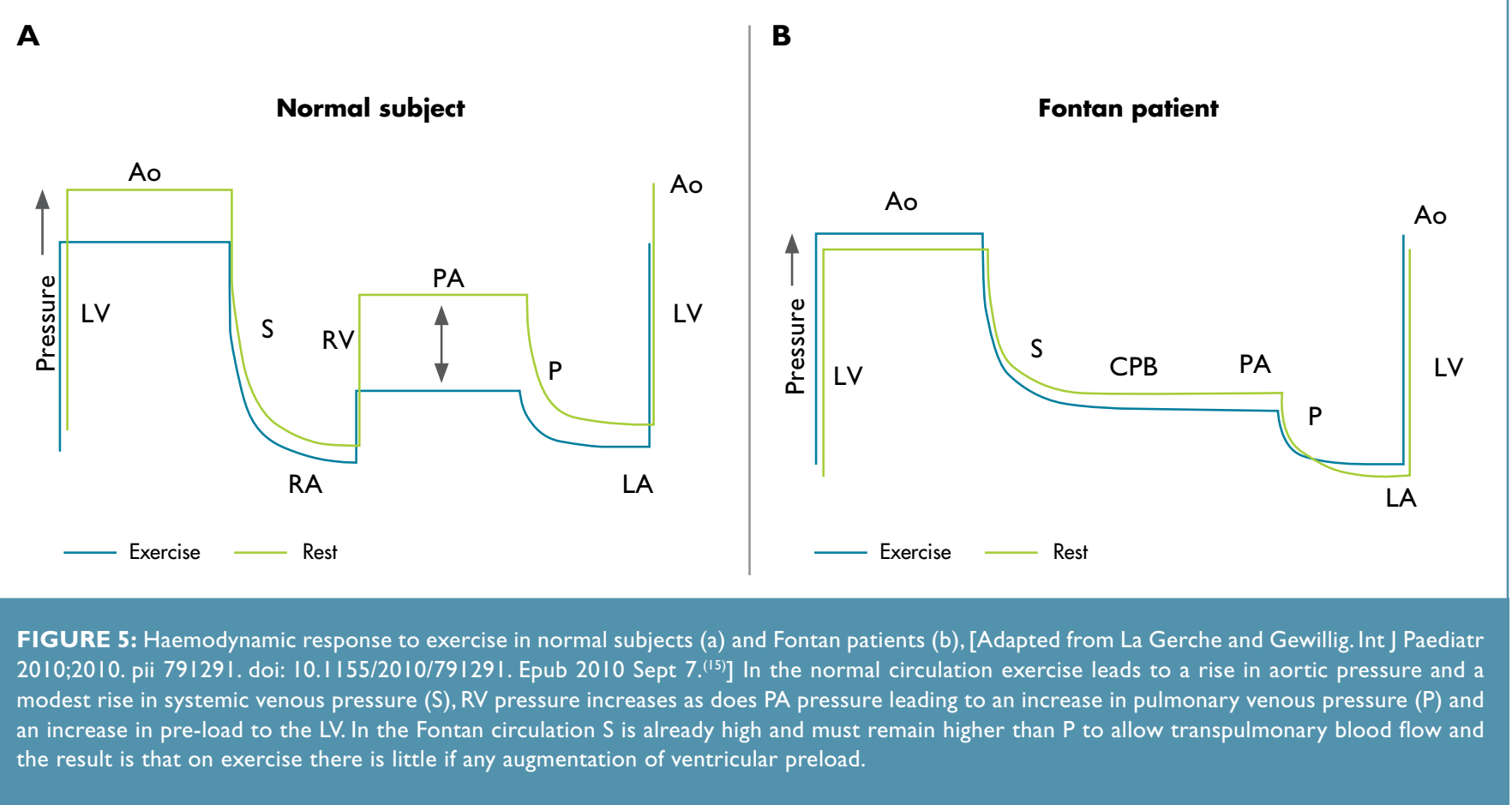

$L V=$ left ventricle. $A o=$ aorta. $R A=$ right atrium. $R V=$ right ventricle. $P A=$ pulmonary artery. $L A=$ left atrium. $C P B=$ cavopulmonary bypass. 
Many of our patients are transitioned on ACE inhibitors and whilst there is little evidence base to support their use, ${ }^{(24,25)}$ we feel that there is no need to stop ACE inhibition and this is continued, often with a dose adjustment to adult dosage.

Imaging modalities used in adult congenital heart patients Transthoracic echocardiography (TTE) is our routine imaging modality. We have an experienced group of technicians who understand the anatomy of the various defects and the surgically altered hearts. This knowledge is built up over time and requires an ongoing process of professional development.

Echocardiography is excellent at imaging ventricular function, outflow tract obstruction and atrioventricular valve structure and function. It is not easy or often possible to assess Fontan pathway flow, obstruction and pulmonary venous pathway obstruction by TTE, so we also routinely use cardiac MRI to examine the Fontan pathway flow, to exclude obstruction and to look at the pulmonary venous return plus the other extra cardiac structures.

Transoesophageal echocardiography (TOE) in experienced hands can yield much of the information that TTE cannot. The pulmonary venous return is easily identified as is any thrombus within the Fontan circuit and clear views of the atrioventricular valves are obtained. Whilst we try to perform these cases under light sedation, many of the patients may require a general anaesthetic (GA).

Cardiac MRI for the Fontan circulation requires experienced technical support and radiologist or imaging cardiologist support. It provides single ventricle functional data, can look at Fontan pathway flow, ${ }^{(26,27)}$ exclude obstruction and look at pulmonary venous return. ${ }^{(28,29)}$ In the HLHS post Norwood, it is the modality of choice for examining the Damus connection and the reconstructed aortic arch. It is time consuming and patients often find the magnetic claustrophobic and therefore cardiac MRI is not possible for all. It is also not possible to image patients with permanent pacemakers in the magnet. We have recently used gated cardiac CT in some individuals although our experience in this modality is insufficient to allow its true role to be established.

Cardiac catheterisation is used less in adults than in children, and again often requires a GA. However it does yield a wealth of information, both functional and pressure data and indirect estimates of cardiac output by measurement of the mixed venous saturation. Great care must be taken to ensure accurate zeroing of the pressure tracings as gradients as little as $1-2 \mathrm{mmHg}$ may be significant in these patients. We also use cardiac catheterisation to guide our interventions, often with TOE guidance. In adults catheter based interventions are not common, but may include stenting of branch pulmonary artery stenosis or venous pathway obstruction. ${ }^{(30)}$ Coil or vascular plug embolisation of collaterals may be necessary in the profoundly cyanosed and also in patients with aortobronchial fistula, presenting with haemoptysis. ${ }^{(31-33)}$

\section{Assessment of exercise performance}

Exercise testing is carried out at transition for nearly all ACHD patients. Whilst we previously used a standard Bruce protocol, this has proven to be a poor tool for discriminating who is limited. We now use cardiopulmonary exercise testing as a routine and the ability to demonstrate when a maximal test has been performed is key. The test will discriminate between respiratory, cardiac or neuromuscular causes of exercise limitation and can be used to guide the timing of and assessing the efficacy of an intervention. We prefer to use in the able bodied a RAMP protocol on a standard treadmill, with continuous assessment of gas exchange. We routinely record the peak oxygen consumption $\left(\mathrm{pVO}_{2}\right)$, the respiratory exchange ratio (RER), the oxygen pulse, the anaerobic threshold (AT) and the $\mathrm{VE} / \mathrm{VCO}_{2}$ slope. These can then be tracked in subsequent tests to assess for deterioration.

Typically a Fontan patient will manage a $\mathrm{pVO}_{2}$ around $60-70 \%$ of predicted values, ${ }^{(24)}$ indicating a severe level of limitation and yet many may express little if any limitations to activities. Whilst the reasons for this are complex, Fontan patients in childhood are often advised to limit their activities and yet there is evidence for the benefits of exercise for Fontan patients. ${ }^{(35,36)}$

\section{Holter monitoring}

Whilst many would advocate routine ambulatory ECG monitoring for all Fontan patients, we are guided by symptoms and in the asymptomatic patient we would not routinely do this. However we do pursue the cause of palpitations in those who report symptoms and would advocate ambulatory ECG monitoring, event recorders and in some reveal devices. It is ideal to be able to demonstrate what the clinically relevant arrhythmia is to our electrophysiology colleagues, so that they can plan ablation procedures. Whether routine electrophysiology studies will be a standard of care for these patients remains uncertain. 


\section{Pregnancy and contraception}

A number of centres have reported the outcomes of pregnancies in women with a Fontan circulation. ${ }^{(37-39)}$ In general both fetal and maternal outcomes in pregnancies carried to term are good, however there is a high risk of fetal loss in the first two trimesters and an increased risk of prematurity. Careful pre-pregnancy assessment and counseling is warranted and we provide this through a dedicated combined obstetric cardiology clinic and patients are monitored throughout their pregnancy. Specific issues encountered are the need to convert warfarin to low molecular weight heparin for the duration for the pregnancy, with the need for weekly antiXa monitoring. Patients on an ACE inhibitor need to stop this for the duration of the pregnancy. The delivery plan is discussed with the obstetrician, anaesthetist and cardiologist, generally we prefer a normal vaginal delivery at term with a short second stage. Caesarian sections are not mandated and may lead to haemodynamic instability and require careful fluid management.

Following pregnancy we aim to repeat the baseline imaging and exercise testing around 6 months postpartum to assess what, if any, effects the pregnancy may have had on cardiac function and performance.

Contraception councelling for Fontan patients is important. Oestrogen containing contraception is not recommended as this may increase the risk of venous thromboembolism. We advocate progestogen only contraception in the form of Cerazette, Nexplanon or Depo-provera. The Mirena coil is effective and safe for those who have undergone a pregnancy, but is not advisable in those who are nulliparous. Barrier methods are cardiac safe but are not as effective.

\section{LONG TERM COMPLICATIONS OF THE FONTAN CIRCULATION}

\section{Atrial Arrhythmias}

A frequent and life threatening complication is the occurrence of sustained atrial arrhythmias. ${ }^{(40,41)}$ The prompt recognition of the abnormal rhythm allows for rapid management of the arrhythmia which can be life saving. Our experience is that we are often called by an emergency room physician who is seeing a Fontan patient who reports an arrhythmia but who is in a normal rhythm.

Typically the arrhythmia takes the form of a macro re-entry scar related tachycardia. Due to the extent of scarring in the atrial mass, the cycle length of the arrhythmia is typically long leading to a modest tachycardia of around 110-130 bpm. The ECGs below (Figures 6a, 6b, 6c) are taken from the same patient. They represent two clinical arrhythmias and one is in sinus rhythm. They were all initially reported as normal.

The consequences of a failure to act swiftly can be fatal. The tachycardia leads to a relative increase in the pulmonary venous atrial pressure, reducing the transpulmonary blood flow, reducing ventricular pre-load and cardiac output. The Fontan circuit is particularly susceptible to reductions in pre-load as discussed above, and patients may rapidly become compromised. Prompt action is required. The patient must be considered for synchronised DC cardioversion at the earliest opportunity. Whilst nil by mouth, they must be given intravenous fluids to support the systemic venous blood pressure that drives the transpulmonary blood flow. Fluids should be given where possible, by an air filtered line. Cardioversion under sedation is safe, but patients often prefer a GA. This should be performed by an experienced anaesthetist with slow intravenous anaesthesia, bearing in mind the compromised circulation and the slow flow through the Fontan circulation. Care should be given not to drop the systemic vascular resistance as this may cause circulatory collapse, and we will have an alphal-adrenergic receptor agonist, such as metaraminol available to support the systemic vascular resistance (SVR) if necessary. Rapid synchronised DC cardioversion is then performed, using 200j in a monophasic defibrillator and 150j in a biphasic defibrillator, a rapid sequence of shocks is appropriate if the initial shock does not restore sinus rhythm.

Following successful cardioversion in a Fontan patient or any other complex congenital heart lesion, our current strategy is to offer electrophysiology studies (EPS) with a view to performing radio-frequency ablation of the scar related flutter circuit. The advent of 3D mapping systems has aided the management of these complex arrhythmias. ${ }^{(42)}$ Our standard medical therapy is beta-blockade with a cardio-selective agent, typically bisoprolol. Some advocate the use of sotalol owing to its additional class 3 activity. ${ }^{(43)}$ We reserve amiodarone for recurrent atrial arrhythmias or sustained ventricular arrhythmias. The prolonged use of amiodarone has a high risk of thyroid dysfunction ${ }^{(43,44)}$ and photosensitivity reactions can be a major problem.

Whether an elective EP study for all adult Fontan patients is justified remains to be determined, but this may be warranted, especially 
$\mathbf{A}$

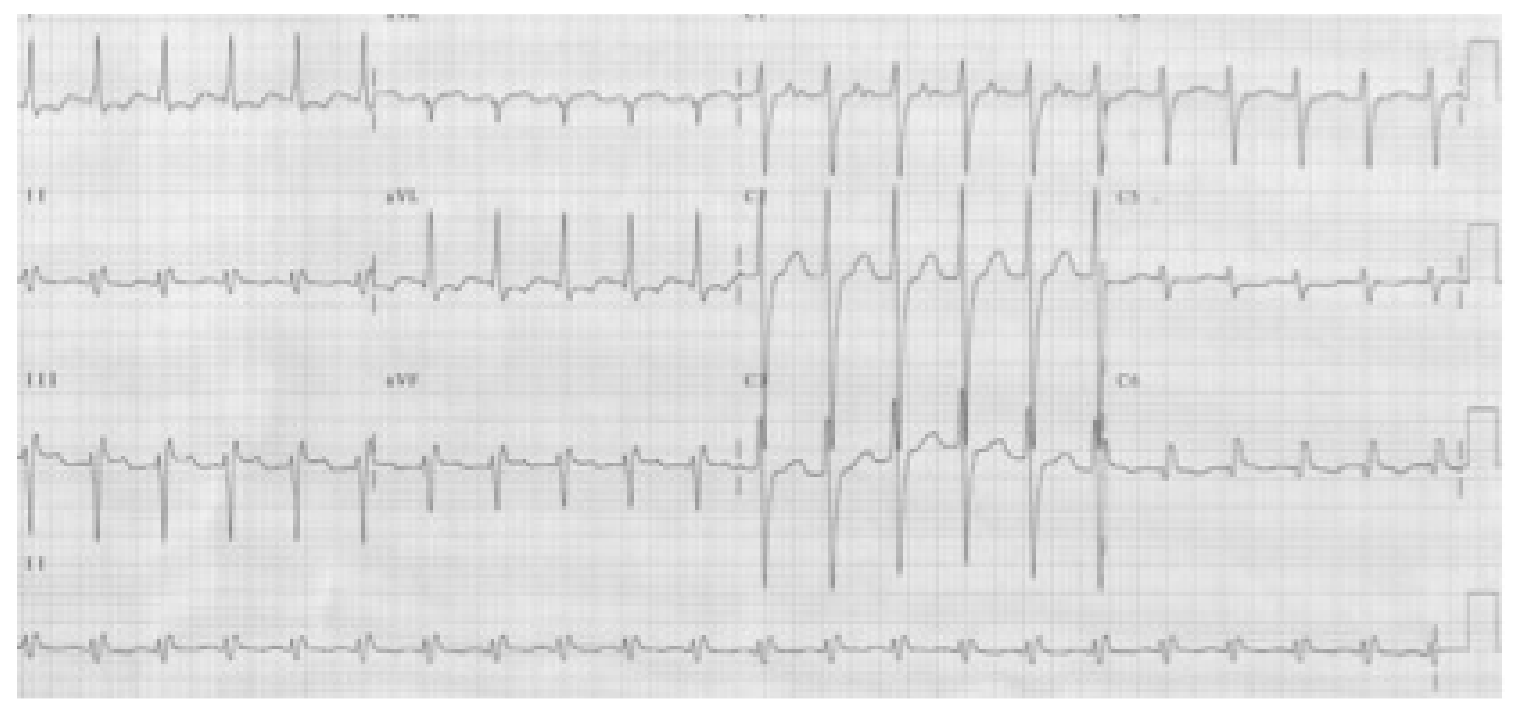

B

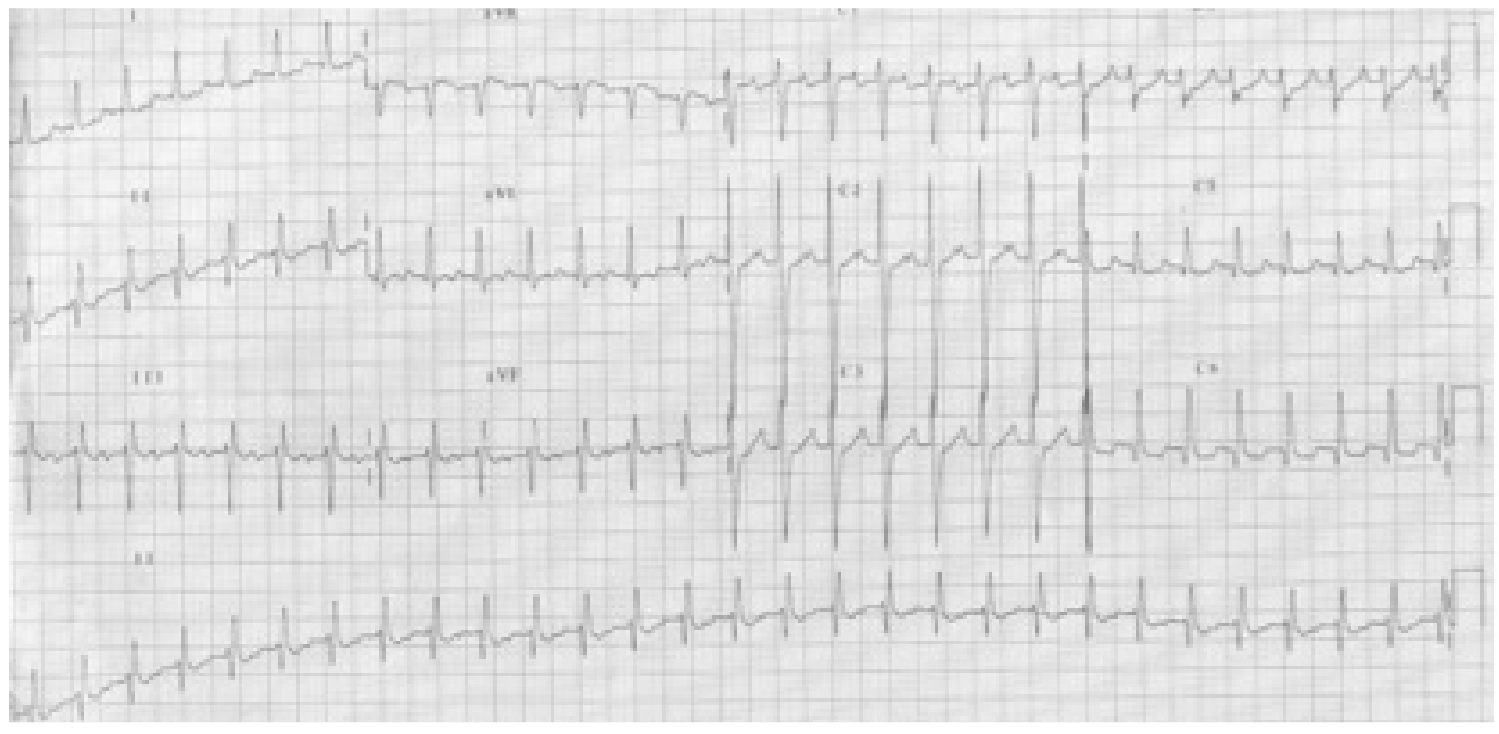

C

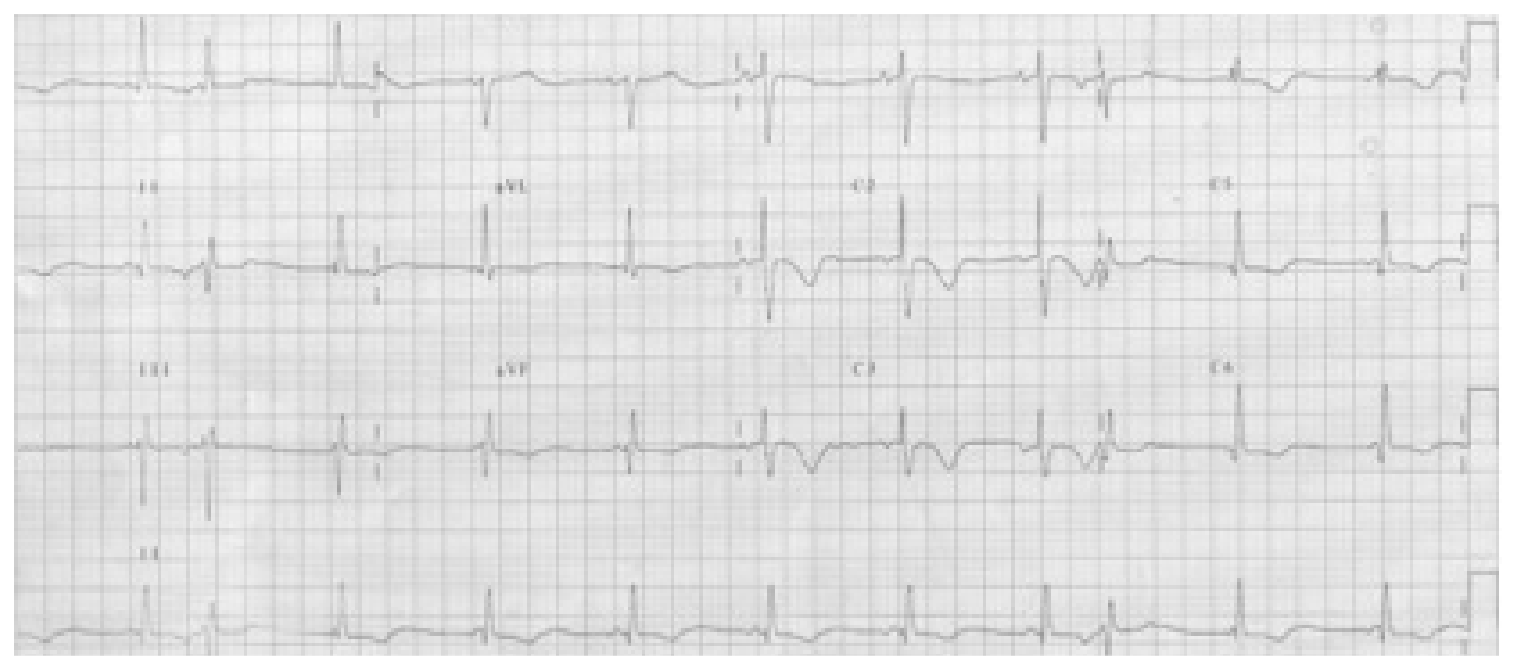

FIGURE 6: 12 lead ECG taken from the same patient with a Fontan circulation.

A: A macro-reentrant atrial tachyarrhythmia. Note the relatively long cycle length.

B: A different macro-reentrant atrial tachyarrhythmia with a shorter cycle length.

C: Normal sinus rhythm. 


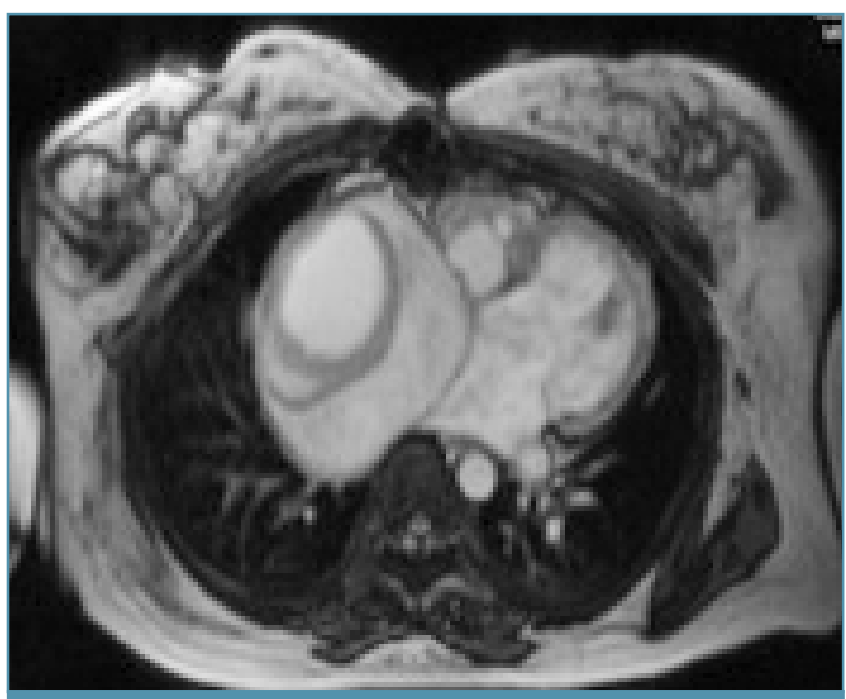

FIGURE 7: Cardiac MRI scan showing a large thrombus within an atriopulmonary Fontan chamber.

given the association of arrhythmias and mortality in these patients. (45,46) There will be difficulties encountered in EPS in patients with an extra-cardiac conduit Fontan, as there is no direct connection between the venous system and the atrial mass, however there are potential strategies. ${ }^{(47)}$

\section{Thromboembolism}

The Fontan circuit by virtue of the low flow at rest and the lack of a sub-pulmonary ventricle is prone to thromboembolic phenomena. The abnormalities in clotting factors occur due to the Fontan circuit formation ${ }^{(48-50)}$ and although the incidence of thromboembolism is lower in TCPC Fontan patients, ${ }^{(21)}$ it can nevertheless occur $^{(51)}$ and we advocate anticoagulation with warfarin for all Fontan patients regardless of type.

Thrombus may present with evidence of pathway obstruction, such as ascites and the onset of protein losing enteropathy associated with effort tolerance and must be actively excluded. We use CT and MRI to look for patency of the Fontan pathway and the pulmonary arteries. Once demonstrated the management is difficult, routine anticoagulation with low molecular weight heparin and oral anticoagulation for those not routinely anticoagulated may be sufficient. Case reports have described successful outcomes with catheter delivered thrombolysis ${ }^{(52)}$ and even surgical embolectomy ${ }^{(53,54)}$ and Fontan conversion surgery, ${ }^{(55,56)}$ however, a large occlusive thrombus is frequently fatal, regardless of management strategy. ${ }^{(53,57)}$ Figures 7 and 8 each show a large thrombus in the right atrium of an AP Fontan patient, with Tricuspid Atresia. Patient I underwent a successful surgical removal and conversion to an

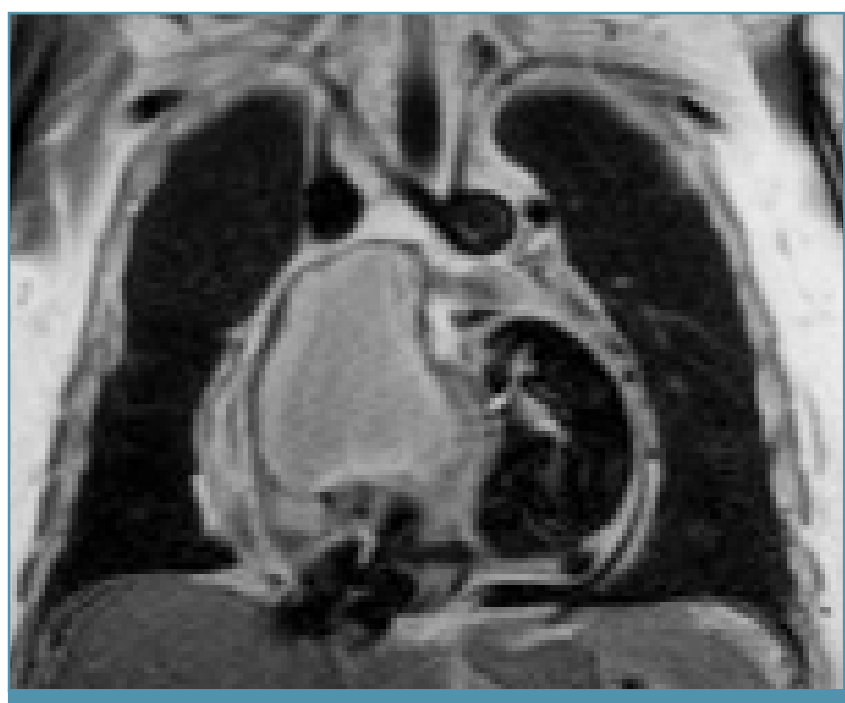

FIGURE 8: Cardiac MRI showing near occlusion of the atriopulmonary Fontan chamber by thrombus.

extra-cardiac TCP Fontan, Patient 2, presented late with occlusion of his left pulmonary artery (LPA) and near total occlusion of his right atrium as can be seen on this black blood MRI image. He had a classical Glenn and died despite full anticoagulation.

\section{Fontan pathway obstruction}

Even a minor degree of Fontan pathway narrowing can lead to significant haemoydynamic compromise. This can occur at the site of the RA-PA connection in the AP Fontan or at the insertion point of the SVC, lateral tunnel or extracardiac conduit in the TCPC Fontan, at the site of insertion of a previous systemic to pulmonary arterial shunt, or typically post Norwood Stage I with narrowing of the LPA as it passes by the reconstructed Damus connection. ${ }^{(58,59)}$ These narrowed parts of the Fontan circuit would typically be addressed in the catheter laboratory with balloon dilatation or stent implantation in the older child and adult. ${ }^{(30,60-62)}$

\section{Pulmonary venous pathway obstruction}

One of the unwanted effects of the modified atriopulmonary Fontan operation was dilatation of the right atrium, such that the right sided pulmonary veins became compressed. ${ }^{(63)}$ This leads to an increase in the pulmonary vascular resistance and is associated with Fontan failure and is an indication for Fontan conversion surgery ${ }^{(55,64)}$ to a total cavopulmonary connection where compression of the veins is less likely.

\section{Sub-aortic obstruction}

The presence sub-aortic stenosis in the univentricular heart used to present the surgeon with great difficulty and any operation 
was associated with a high mortality ${ }^{(65)}$ until the adaptation of the Norwood I operation for use in this particular anatomy. ${ }^{(66)}$ Whilst the Damus operation has evolved as the treatment of choice for patients presenting with sub-aortic stenosis, there remains a small proportion of patients for whom this is a late complication following Fontan surgery. ${ }^{(67-70)}$ Surgery remains the standard management for this complication and can take the form of a sub-aortic resection ${ }^{(71)}$ or late formation of a Damus connection. ${ }^{(72,73)}$ However, this comes at a cost of significant operative mortality. ${ }^{(71)}$ High risk patients include those with univentricular hearts and transposition of the great vessels. ${ }^{(74,75)}$

In our experience patients have presented with effort intolerance and anginal symptoms but also asymptomatic with a progressive severe sub-aortic muscular obstruction. It remains a risk in many of the patients who have undergone a Fontan operation, and should be looked for during routine TTE.

\section{Systemic atrioventricular valve regurgitation (AVVR)}

The mechanism of AVVR in patients with a univentricular circulation remains poorly understood. It occurs in the non-palliated univentricular circulation ${ }^{(76,77)}$ and may be addressed at the time of Fontan completion. ${ }^{(78,79)}$ The development of AVVR post Fontan surgery is associated with morbidity and mortality ${ }^{(80-82)}$ and surgery to repair the regurgitant valve is also associated with significant early and late mortality ${ }^{(83)}$ however, if successful also leads to improvements in ventricular function. ${ }^{(84)}$

\section{Ventricular Dysfunction}

The single ventricle pre-Fontan surgery is a chronically volume loaded chamber which undergoes adverse geometric changes if left volume loaded. ${ }^{\left({ }^{85}\right)}$ The Fontan operation leads to early improvements in ventricular function and hypertrophy. ${ }^{(86-88)}$ By adult life the gains in ventricular function are largely lost with around a third of reported patients having moderate or severe ventricular function. ${ }^{\left({ }^{89}\right)}$ There are many plausible theories as to why late ventricular function occurs, with increasing systemic vascular resistance, due to abnormal vascular tone, ${ }^{(90)}$ endothelial dysfunction, ${ }^{(91-93)}$ and the abnormal resistances encountered by the pulmonary and systemic circulations running in series ${ }^{(6)}$ all probably playing a part. The onset of significant valvular incompetence and the onset of atrial arrhythmias are both poorly tolerated.

Whilst there is a lack of evidence base for the use of conventional heart failure treatment, nevertheless there is little else to offer. Spironolactone may improve endothelial function ${ }^{(93)}$ and carvedilol appears to improve systemic ventricular function ${ }^{(94)}$ in Fontan patients, yet the role of ACE inhibitors remains unproven ${ }^{(24)}$ despite their routine use alongside empirical use of diuretics.

\section{Protein-losing enteropathy (PLE)}

PLE is a devastating late complication of the Fontan operation. ${ }^{(95)}$ It is associated with chronic protein loss from the gastrointestinal tract ${ }^{(96)}$ and the presence of elevated fecal alpha-I antitrypsin levels in association with a low serum albumin and generalised oedema is characteristic. ${ }^{(97,98)}$ The exact cause remains uncertain but chronic elevation of systemic venous pressures, lymphatic dysfunction, ${ }^{(99,100)}$ ventricular dysfunction, ${ }^{(101,102)}$ abnormal pulmonary vascular compliance ${ }^{(103)}$ and intestinal heparan loss ${ }^{(104)}$ have all been implicated. Pathway obstruction must be actively looked for and treated $(98,102,105)$ and there are reports of PLE resolution by conversion to a TCPC Fontan ${ }^{(64,106,107)}$ and by cardiac transplantation, ${ }^{(108,109)}$ however, both are technically challenging even without the presence of PLE and are associated with significant procedural mortality.

Many possible therapies have been suggested and these are directed symptomatic relief with diuretics ${ }^{(1 / 0)}$ and dietary modifications, ${ }^{(111112)}$ reduction in intestinal protein loss with the use of steroids ${ }^{(113-116)}$ and heparin ${ }^{(117-123)}$ and improving the haemodynamics as described above.

\section{Cyanosis}

A degree of cyanosis is common in most adult Fontan patients, in many due to a fenestration made at the time of Fontan completion in order to maintain cardiac output in the early post operative period with an associated reduction in morbidity and mortality. ${ }_{(10,124)}$ Later percutaneous closure of the fenestration is often performed if cyanosis is profound and may be complete occlusion $^{(125-127)}$ or partial. ${ }^{(128,129)}$ Similarly, baffle leaks in the suture line of the fontan circuit, may lead to cyanosis which may be closed percutaneously. ${ }^{(130)}$ Venous collaterals are also common and may be addressed in the catheter lab. ${ }^{(131,132)}$ Extra cardiac causes can occur and in some patients a severe restrictive lung defect may also occur, further impairing gas exchange.

Cyanosis is a multi-system disorder, typically the patient may have impaired clotting, with low platelet counts and abnormal clotting factors. They are at risk of acute renal injury and every effort must be made to keep the patient well hydrated and avoidance of nephrotoxic agents is advised. As with all cyanotic cardiac patients, 
the resting right to left shunt places the patient at risk of systemic paradoxical emboli, and all intravenous fluids/injections should be given via filtered lines. Also if unexplained neurological symptoms develop, patients should undergo screening for a cerebral abscess, a rare but significant complication of cyanotic heart disease.

\section{Bradyarrhythmias}

Whilst bradyarrhythmias are not typical post Fontan surgery, they are difficult to manage. Endovascular pacing of the single ventricle is often not possible without a "transeptal puncture" and a systemic ventricular pacing lead is not considered ideal due to the risk of thromboembolic complications. In those with pure sinus node dysfunction endovascular atrial pacing is a good option. ${ }^{(132,133)}$ The majority of ventricular pacing is epicardial. ${ }^{(134,135)}$ This requires at best a limited thorocotomy and may require full sternotomy and cardiopulmonary bypass, with the associated risks. In some patients access to the coronary sinus is possible via the Fontan circuit and in these "LV" leads have been placed with some success. ${ }^{(136-139)}$ Lead failure is not uncommon and again this is difficult to manage. ${ }^{(134,140)}$

Many centres will place epicardial pacing leads if a patient is undergoing conversion from an atriopulmonary to a TCPC Fontan as the risk of bradyarrhythmias is higher following the arrhythmia surgery typically performed during this operation. ${ }^{(141,142)}$

\section{Hepatocellular carcinoma}

Chronic elevation of the hepatic venous pressure is thought to lead to chronic liver pathology and there are a number of reported cases of hepatocellular carcinoma occurring late after Fontan surgery. (143-145) Screening for hepatic adenomas by annual liver imaging and alpha-feto protein levels has been recommended and is a low cost way of identifying these cases early in their disease course. $^{(146-148)}$

\section{Prognosis}

It is clear that the management of the univentricular circulation is a success story if considered in terms of survival benefit. Inevitable death in childhood has been turned into likely survival to adult life for the majority, yet it comes at a cost. The burden of impaired effort tolerance, the risk of arrhythmias and the likely decline into a low cardiac output state, whilst still a young adult, is considerable. We do not know what the long term prognosis is for these patients. In the largest and longest follow up series published, a third of patients had died following a mean follow up period of 12 years. Yet the majority of these deaths were peri-operative and in survivors, 20 year survival rates were $82 \% .{ }^{(19)}$ It is possible that surgical modifications will lead to improvements in early and late survival but that remains unproven. However, the success of the Norwood palliation for HLHS will also impact on these survival figures. ${ }^{(149)}$

Survival for patients with an atriopulmonary Fontan may improve by conversion to a TCPC type Fontan. ${ }^{(150)}$ The associated improvement in fluid mechanics and reduction in arrhythmia burden are likely to lead to survival improvements, but the operation requires careful consideration. ${ }^{(151)}$ In carefully selected patients, the operation is associated with a low operative mortality. ${ }^{(151,152)}$

\section{Role of transplantation}

The difficulties of cardiac transplantation in patients with congenital heart disease has already been discussed in this journal (Bowater 2013) and its use in Fontan patients is well described. ${ }^{(153,154)}$ Early mortality is high ${ }^{(155-157)}$ but later survival for those transplanted for impaired ventricular function is good. PLE prior to

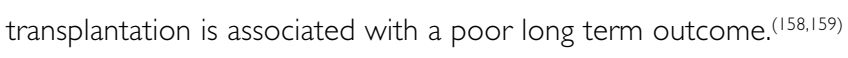
With improving early survival from staged Fontan surgery, there will be an inevitable increase in adults with failing Fontan circulations in whom transplantation will be considered. The prospect of a mechanical Fontan support device has been raised and a number of designs have undergone mathematical modeling (160,161) and animal studies. ${ }^{(162-164)}$

\section{Conflict of interest: none declared.}




\section{REFERENCES}

1. Fontan F and Baudet E. Surgical repair of tricuspid atresia. Thorax 1971; 26(3):240-248.

2. Doty DB, Marvin WJ Jr., Lauer RM. Modified Fontan procedure. Methods to achieve direct anastomosis of right atrium to pulmonary artery. J Thorac Cardiovasc Surg 1981;81 (3):470-475.

3. Choussat AFF, Besse P. Selection criteria for Fontan's procedure. Paediatric cardiology. SE Anderson RH. Edinburgh, Churchill Livingstone: 1978;559-566.

4. Fontan F, Kirklin JW, Fernandez G, et al. Outcome after a "perfect" Fontan operation. Circulation 1990;81 (5): I520-1536.

5. Hosein RB, Clarke AJ, McGuirk SP, et al. Factors influencing early and late outcome following the Fontan procedure in the current era. The "Two Commandments"? Eur J Cardiothorac Surg 2007;3I (3):344-352; discussion 353.

6. Senzaki H, Masutani S, Kobayashi J, et al. Ventricular afterload and ventricular work in fontan circulation: comparison with normal two-ventricle circulation and single-ventricle circulation with blalock-taussig shunts. Circulation 2002; 105(24):2885-2892.

7. De Leval MR, Kilner P, Gewillig M, et al. Total cavopulmonary connection: A logical alternative to atriopulmonary connection for complex Fontan operations. Experimental studies and early clinical experience. J Thorac Cardiovasc Surg 1988;96(5):682-695.

8. Pearl JM, Laks H, Stein DG, et al. Total cavopulmonary anastomosis versus conventional modified Fontan procedure. Ann Thorac Surg 1991;52(2):189-196.

9. Laschinger JC, Ringel RE, Brenner Jl, et al. The extracardiac total cavopulmonary connection for definitive conversion to the Fontan circulation: Summary of early experience and results. J Card Surg 1993;8(5): 524-533.

10. Bridges ND, Mayer JE Jr., Lock JE, et al. Effect of baffle fenestration on outcome of the modified Fontan operation. Circulation 1992;86(6): 1762-1769.

II. Norwood WI, Lang P, Casteneda AR, et al. Experience with operations for hypoplastic left heart syndrome. J Thorac Cardiovasc Surg 1992;82(4):5 I I-519.

12. Gates RN, Laks H, Elami A, et al. Damus-Stansel-Kaye procedure: current indications and results. Ann Thorac Surg 1993;56(1): I I I-1 19

13. Barron DJ, Kilby MD, Davies B, et al. Hypoplastic left heart syndrome. Lancet 2009;374(9689):55I-564.

14. De Leval MR. The Fontan circulation: A challenge to William Harvey? Nat Clin Pract Cardiovasc Med 2005;2(4):202-208.

15. La Gerche A, Gewillig M. What limits cardiac performance during exercise in normal subjects and in healthy Fontan patients? Int J Paediatr 2010;2010. pii 79|291. doi: 10.1155/2010/791291. Epub 2010 Sept 7.

16. Gewillig M, Brown SC, Eyskens B, et al. The Fontan circulation: Who controls cardiac output? Interact Cardiovasc Thorac Surg 20 I 0; 10(3):428-433.

17. Balling $\mathrm{G}$, Vogt $\mathrm{M}$, Kaemmerer $\mathrm{H}$, et al. Intracardiac thrombus formation after the Fontan operation. J Thorac Cardiovasc Surg 2000; I 19 (4 Pt 1):745-752

18. Tsang W, Johansson B, Salehian $\mathrm{O}$, et al. Intracardiac thrombus in adults with the Fontan circulation. Cardiol Young 2007; 17(6):646-65I.

19. Khairy P, Fernandes SM, Mayer JE Jr., et al. Long-term survival, modes of death and predictors of mortality in patients with Fontan surgery. Circulation 2008: 1 17(1): 85-92

20. Jacobs ML, Pourmoghadam KK, Geary EM, et al. Fontan's operation: is aspirin enough? Is coumadin too much? Ann Thorac Surg 2002;73(I):64-68.

21. Jacobs ML, Pelletier G], Pourmoghadam KK, et al. Protocols associated with no mortality in 100 consecutive Fontan procedures. Eur J Cardiothorac Surg 2008; 33(4): 626-632.

22. Monagle P, Cochrane A, Roberts R, et al. A multicenter, randomised trial comparing heparin/warfarin and acetylsalicylic acid as primary thromboprophylaxis for 2 years after the Fontan procedure in children. J Am Coll Cardiol 201 1;58(6): 645-65।

23. Potter BJ, Leong-Sit P, Fernandes SM, et al. Effect of Aspirin and warfarin therapy on thromboembolic events in patients with univentricular hearts and Fontan palliation. Int J Cardiol 2013

24. Kouatli AA, Garcia JA, Zellers TM, et al. Enalapril does not enhance exercise capacity in patients after Fontan procedure. Circulation 1997;96(5): I507- 1512.
25. Heragu N, Mahony. Is captopril useful in decreasing pleural drainage in children after modified Fontan operation? Am J Cardiol 1999.84(9): I I09- I I I2, a I I 10.

26. Hjortdal VE, Emmertsen K, Stenbog E, et al. Effects of exercise and respiration on blood flow in total cavopulmonary connection: A real-time magnetic resonance flow study. Circulation 2003; 108(10): | 227-|231.

27. Takawira F, Ayer JG, Onikul E, et al. Evaluation of the extracardiac conduit modification of the Fontan operation for thrombus formation using magnetic resonance imaging. Heart Lung Circ 2008; 17(5): 407-4I0.

28. Fogel MA, Hubbard A, Weinberg PM. A simplified approach for assessment of intracardiac baffles and extracardiac conduits in congenital heart surgery with two- and three-dimensional magnetic resonance imaging. Am Heart J 1002: | 42(6): | 028 - 1036

29. Fogel MA. Cardiac magnetic resonance of single ventricles. J Cardiovasc Magn Reson 2006;8(4):661-670.

30. Ovroutski S, Ewert P, Alexi-Meskishvili V, et al. Dilatation and stenting of the fontan pathway: Impact of the stenosis treatment on chronic ascites. J Interv Cardiol 2008;2I ( I):38-43.

31. Kaulitz R, Ziemer G, Paul T, et al. Fontan-type procedures: residual lesions and late interventions. Ann Thorac Surg 2002;74(3):778-785

32 Sugiyama $H$, Yoo SJ, Williams $W$ et al. Characterisation and treatment of systemic venous to pulmonary venous collaterals seen after the Fontan operation. Cardiol Young 2003; I3(5):424-430.

33. Banka P, Sleeper LA, Atz AM, et al. Practice variability and outcomes of coil embolisation of aortopulmonary collaterals before Fontan completion: A report from the Paediatric Heart Network Fontan Cross-Sectional Study. Am Heart 2011;162(1):125-130

34. Kempny A, Dimopoulos K, Uebing A, et al. Reference values for exercise limitations among adults with congenital heart disease. Relation to activities of daily life - single centre experience and review of published data. Eur Heart J 2012;33(I I):1386-1396.

35. Opocher F, Varnier M, Sanders SP, et al. Effects of aerobic exercise training in children after the Fontan operation. Am J Cardiol 2005;95( I): I 50- I 52.

36. Brassard $\mathrm{P}$, Poirier $\mathrm{P}$, Martin J, et al. Impact of exercise training on muscle function and ergoreflex in Fontan patients: a pilot study. Int J Cardiol 2006; 107(1):85-94.

37. Canobbio MM, Mair DD, van der Velde M, et al. Pregnancy outcomes after the Fontan repair. J Am Coll Cardiol 1996;28(3):763-767.

38. Hoare JV, Radford D. Pregnancy after fontan repair of complex congenital heart disease. Aust N Z J Obstet Gynaecol 200 I;4I (4): 464-468.

39. Drenthen W, Pieper PG, Roos-Hesselink JW, et al. Pregnancy and delivery in women after Fontan palliation. Heart 2006;92(9): I 290- 1294

40. Cecchin F, Johnsrude CL, Perry JC, et al. Effect of age and surgical technique on symptomatic arrhythmias after the Fontan procedure. Am J Cardiol 1995; 76(5):386-391.

41. Deal BJ, Mavroudis C, Backer CL. Arrhythmia management in the Fontan patient. Paediatr Cardiol 2007;28(6):448-456

42. Lam W, Friedman RA. Electrophysiology issues in adult congenital heart disease. Methodist Debakey Cardiovasc J 2011;7(2): 13-17.

43. Koyak Z, Kroon B, de Groot JR, et al. Efficacy of Antiarrhythmic Drugs in Adults With Congenital Heart Disease and Supraventricular Tachycardias. Am J Cardiol 2013.

44. Thorne SA, Barnes I, Cullinan P, et al. Amiodarone-associated thyroid dysfunction: risk factors in adults with congenital heart disease. Circulation 1999; 100(2): 149- 154.

45. Diller GP, Giardini A, Dimopoulos K, et al. Predictors of morbidity and mortality in contemporary Fontan patients: Results from a multicenter study including cardiopulmonary exercise testing in 321 patients. Eur Heart J 2010;31(24): 3073-3083.

46. Giannakoulas G, Dimopoulos K, Yuksel S, et al. Atrial tachyarrhythmias late after Fontan operation are related to increase in mortality and hospitalisation. Int J Cardiol 2012;157(2):221-226. 
47. Ernst S, Babu-Narayan SV, Keegan J, et al. Remote-controlled magnetic navigation and ablation with $3 \mathrm{D}$ image integration as an alternative approach in patients with intra-atrial baffle anatomy. Circ Arrhythm Electrophysiol 20 I2;5(1): I 31-139.

48. Cromme-Dijkhuis AH, Henkens CM, Bijleveld CM et al. Coagulation factor abnormalities as possible thrombotic risk factors after Fontan operations. Lancet 1990;336(8723): 1087-1090.

49. Jahangiri $M$, Shore $D$, Kakkar $V$, et al. Coagulation factor abnormalities after the Fontan procedure and its modifications. J Thorac Cardiovasc Surg 1997; II3(6): 989-992; discussion 992-983.

50. Rauch R, Ries M, Hofbeck M, et al. Haemostatic changes following the modified Fontan operation (total cavopulmonary connection). Thromb Haemost 2000; 83(5):678-682

51. Chowdhury UK, Airan B, Kothari SS, et al. Specific issues after extracardiac fontan operation: ventricular function, growth potential, arrhythmia, and thromboembolism. Ann Thorac Surg 2005;80(2):665-672.

52. Ruud E, Holmstrom $H$, Aagenaes I, et al. Successful thrombolysis by prolonged low-dose alteplase in catheter-directed infusion. Acta Paediatr 2003; 92(8):973-976

53. Hedrick M, Elkins RC, Knott-Craig CJ et al. Successful thrombectomy for thrombosis of the right side of the heart after the Fontan operation. Report of two cases and review of the literature. J Thorac Cardiovasc Surg 1993; 105(2):297-301.

54. Soyer R, Bouchart F, Bessou JP, et al. Right atrial thrombosis; an unusual late complication of the Fontan procedure. Apropos of a case. Arch Mal Coeur Vaiss 1995;88(3):391-395.

55. McElhinney DB, Reddy VM, Moore P, et al. Revision of previous Fontan connections to extracardiac or intraatrial conduit cavopulmonary anastomosis. Ann Thorac Surg 1996;62(5): I276- I282; discussion 1283.

56. Marcelletti CF, Hanley FL, Mavroudis C, et al. Revision of previous Fontan connections to total extracardiac cavopulmonary anastomosis: A multicenter experience. J Thorac Cardiovasc Surg 2000; 11 9(2):340-346.

57. Konstantinov IE, Puga FJ, Alexi-Meskishvili VV. Thrombosis of intracardiac or extracardiac conduits after modified Fontan operation in patients with azygous continuation of the inferior vena cava. Ann Thorac Surg 200 I;72(5): I 64 | - 644.

58. Moszura T, Mazurek-Kula A, Dryzek P, et al. Interventions complementing surgery as part of multistage treatment for hypoplastic left heart syndrome: One center's experience. Paediatr Cardiol 2009;30(2): 106-113.

59. Reinhardt Z, De Giovanni J, Stickley J, et al. Catheter interventions in the staged management of hypoplastic left heart syndrome. Cardiol Young: 20। 3; I-8.

60. Pelikan P, French WJ, Ruiz C, et al. Percutaneous double-balloon angioplasty of a stenotic modified Fontan aortic homograft conduit. Cathet Cardiovasc Diagn 1988; | 5(1):47-51.

61. O'Laughlin MP, Slack MC, Grifka RG, et al. Implantation and intermediate-term follow-up of stents in congenital heart disease. Circulation 1993;88(2):605-6I4.

62. Mets JM, Bergersen L, Mayer JE Jr., et al. Outcomes of stent implantation for obstruction of intracardiac lateral tunnel Fontan pathways. Circ Cardiovasc Interv 2013;6(1):92-100.

63. Fogel MA, Chin AJ. Imaging of pulmonary venous pathway obstruction in patients after the modified Fontan procedure. J Am Coll Cardiol 1992;20(I): 181-190.

64. Kreutzer J, Keane JF, Lock JE, et al. Conversion of modified Fontan procedure to lateral atrial tunnel cavopulmonary anastomosis. J Thorac Cardiovasc Surg 1996; | | | (6): 1 I69-1176.

65. Penkoske PA, Freedom RM, Williams WG, et al. Surgical palliation of subaortic stenosis in the univentricular heart. J Thorac Cardiovasc Surg 1984;87(5): 767-781.

66. Jonas RA, Castaneda AR, Lang P. Single ventricle (single- or double-inlet) complicated by subaortic stenosis: surgical options in infancy. Ann Thorac Surg 1985; 39(4):361-366.
67. Leung MP, Benson LN, Smallhorn JF, et al. Abnormal cardiac signs after Fontan type of operation: Indicators of residua and sequelae. Br Heart J 1989; 6I (1):52-58.

68. Razzouk AJ, Freedom RM, Cohen AJ, et al. The recognition, identification of morphologic substrate, and treatment of subaortic stenosis after a Fontan operation. An analysis of 12 patients. J Thorac Cardiovasc Surg 1992; 104(4): 938-944.

69. Kasahara S, Nakae S, Kawada M, et al. A case of a univentricular heart developed subaortic stenosis after fontan operation. Nihon Kyobu Geka Gakkai Zasshi 1996;44(1):83-88.

70. Hiramatsu $\mathrm{T}$, Imai $\mathrm{Y}$, Kurosawa $\mathrm{H}$, et al. Midterm results of surgical treatment of systemic ventricular outflow obstruction in Fontan patients. Ann Thorac Surg 2002;73(3):855-860; discussion 860-85।.

71. Podzolkov VP, Zaetz SB, Alekyan BG, et al. Surgical reinterventions after modified Fontan operations. Ann Thorac Surg 1995;60(6 Suppl):S572-577.

72. Karl TR, Watterson KG, Sano S, et al. Operations for subaortic stenosis in univentricular hearts. Ann Thorac Surg 1991;52(3):420-427; discussion 427-428.

73. Karimi M, Rosenberg CA, Lutin W. Damus-Kaye-Stansel procedure 5 years after Fontan operation with ligated main pulmonary artery. Cardiol Young 2013;23(4):613-616.

74. Newfeld EA, Nikaidoh $\mathrm{H}$. Surgical management of subaortic stenosis in patients with single ventricle and transposition of the great vessels. Circulation 1987; 76(3 Pt 2):lii29-33.

75. Lacour-Gayet F, Serraf A, Fermont L, et al. Early palliation of univentricular hearts with subaortic stenosis and ventriculoarterial discordance. The arterial switch option. J Thorac Cardiovasc Surg 1992; 104(5): I 238- 1245.

76. Moak JP, Gersony WM. Progressive atrioventricular valvular regurgitation in single ventricle. Am J Cardiol 1987;59(6):656-658.

77. Imai $Y$, Seo K, Terada M, et al. Valvular repair for atrioventricular regurgitation in complex anomalies in modified Fontan procedure with reference to a single ventricle associated with a common atrioventricular valve. Semin Thorac Cardiovasc Surg Paediatr Card Surg Annu 1999:2:5-19.

78. Sallehuddin A, Bulbul Z, Otero F, et al. Repair of atrioventricular valve regurgitation in the modified Fontan operation. Eur J Cardiothorac Surg 2004; 26(I):54-59.

79. Kerendi F, Kramer ZB, Mahle WT, et al. Perioperative risks and outcomes of atrioventricular valve surgery in conjunction with Fontan procedure. Ann Thorac Surg 2009;87(5): | 484- | 488; discussion |488-| 489.

80. Matsuda $H$, Kawashima $Y$, Kishimoto $H$, et al. Problems in the modified Fontan operation for univentricular heart of the right ventricular type. Circulation 1987;76(3 Pt 2):lii45-52.

81. Parikh SR, Hurwitz RA, Caldwell RL, et al. Ventricular function in the single ventricle before and after Fontan surgery. Am J Cardiol 199 |;67( I 6): | 390- I 395.

82. Knott-Craig C], Danielson GK, Schaff HV, et al. The modified Fontan operation. An analysis of risk factors for early postoperative death or takedown in 702 consecutive patients from one institution. J Thorac Cardiovasc Surg 1995; 109(6): 1237-1243.

83. Menon SC, Dearani JA, Cetta F. Long-term outcome after atrioventricular valve surgery following modified Fontan operation. Cardiol Young 201 1;21 ( I):83-88.

84. Hancock Friesen CL, Sherwood MC, Gauvreau K, et al. Intermediate outcomes of atrioventricular valvuloplasty in lateral tunnel Fontan patients. J Heart Valve Dis 2004; 13(6):962-971; discussion 971.

85. Sluysmans T, Sanders SP, van der Velde M, et al. Natural history and patterns of recovery of contractile function in single left ventricle after Fontan operation. Circulation 1992;86(6): 1753-1761.

86. Kirklin JK, Blackstone EH, Kirklin JW, et al. The Fontan operation. Ventricular hypertrophy, age, and date of operation as risk factors. J Thorac Cardiovasc Surg 1986;92(6): 1049-1064. 


\section{REFERENCES}

87. Gewillig MH, Lundstrom UR, Deanfield JE, et al. Impact of Fontan operation on left ventricular size and contractility in tricuspid atresia. Circulation 1990; 8I(1):118-127.

88. Gewillig M, Daenen W, Aubert A, et al. Abolishment of chronic volume overload. Implications for diastolic function of the systemic ventricle immediately after Fontan repair. Circulation 1992;86(5 Suppl):li93-99.

89. Veldtman GR, Nishimoto A, Siu S, et al. The Fontan procedure in adults. Heart 200।;86(3):330-335.

90. Lambert E, d'Udekem Y, Cheung M, et al. Sympathetic and vascular dysfunction in adult patients with Fontan circulation. Int J Cardiol 20 I3; 167(4): 1333-I 338.

91. Khambadkone S, Li J, de Leval MR, et al. Basal pulmonary vascular resistance and nitric oxide responsiveness late after Fontan-type operation. Circulation 2003; 107(25):3204-3208.

92. Binotto MA, Maeda NY, Lopes AA. Altered endothelial function following the Fontan procedure. Cardiol Young 2008; | (1):70-74.

93. Mahle WT, Wang A, Quyyumi AA, et al. Impact of spironolactone on endothelial function in patients with single ventricle heart. Congenit Heart Dis 2009; $4(1): 12-16$

94. Ishibashi N, Park IS, Waragai T, et al. Effect of carvedilol on heart failure in patients with a functionally univentricular heart. Circ J 201 I;75(6): 1394-1399.

95. Lin WS, Hwang MS, Chung HT, et al. Protein-losing enteropathy after the Fontan operation: clinical analysis of nine cases. Chang Gung Med J 2006;29(5):505-5 I2.

96. Thorne SA, Hooper J, Kemp M, et al. Gastro-intestinal protein loss in late survivors of Fontan surgery and other congenital heart disease. Eur Heart J 1998; | 9(3):5 | 4-520.

97. Hess J, Kruizinga K, Bijleveld CM, Hardjowijono R, et al. Protein-losing enteropathy after Fontan operation. J Thorac Cardiovasc Surg 1984;88(4):606-609.

98. Mertens L, Hagler DJ, Sauer U, et al. Protein-losing enteropathy after the Fontan operation: An international multicenter study. PLE study group. J Thorac Cardiovasc Surg 1998;1 15(5): 1063-1073.

99. Connor FL, Angelides S, Gibson M, et al. Successful resection of localised intestinal lymphangiectasia post-Fontan: Role of $(99 \mathrm{~m})$ technetium-dextran scintigraphy. Paediatrics 2003; I 2 (3 Pt I):e242-247.

100. Meadows J, Gauvreau K, Jenkins K. Lymphatic obstruction and protein-losing enteropathy in patients with congenital heart disease. Congenit Heart Dis 2008 3(4):269-276

101. Feldt RH, Driscoll D], Offord KP, et al. Protein-losing enteropathy after the Fontan operation. J Thorac Cardiovasc Surg 1996; I 12(3):672-680

102. Ohuchi H, Yasuda K, Miyazaki A, et al. Haemodynamic characteristics before and after the onset of protein losing enteropathy in patients after the Fontan operation. Eur J Cardiothorac Surg 20 I3;43(3):e49-57.

103. Yu Jj, Yun TJ, Yun SC, et al. Low pulmonary vascular compliance predisposes post-Fontan patients to protein-losing enteropathy. Int J Cardiol 20।3;165(3): 454-457.

104. Bode L, Murch S, Freeze HH. Heparan sulfate plays a central role in a dynamic in vitro model of protein-losing enteropathy. J Biol Chem 2006;28I (12):7809-78I5.

105. Shahda S, Zahra M, Fiore A, et al. Stents in the successful management of protein-losing enteropathy after fontan. J Invasive Cardiol 2007;19(10):444-446.

106. Kimura K, Fukuda T, Suzuki T, et al. A successful conversion of failed fontan circulation to total cavopulmonary connection in a case of tricuspid atresia without pulmonary stenosis. Jpn J Thorac Cardiovasc Surg 1998;46( I I): | |47- I I 5 I.

107. Van Son JA, Mohr FW, Hambsch J, et al. Conversion of atriopulmonary or lateral atrial tunnel cavopulmonary anastomosis to extracardiac conduit Fontan modification. Eur J Cardiothorac Surg 1999; I5(2): I50- I57; discussion I57- 158.

108. Sierra C, Calleja F, Picazo B, et al. Protein-losing enteropathy secondary to Fontan procedure resolved after cardiac transplantation. J Paediatr Gastroenterol Nutr 1997;24(2):229-230

109. Brancaccio G, Carotti A, D'Argenio P, et al. Protein-losing enteropathy after Fontan surgery: Resolution after cardiac transplantation. The Journal of Heart and Lung Transplantation 2003;22(4):484-486.
110. Ringel RE, Peddy SB. Effect of high-dose spironolactone on protein-losing enteropathy in patients with Fontan palliation of complex congenital heart disease. Am J Cardiol 2003;9I (8): I 031 - 1032, al 039

I I I. Guariso G, Cerutti A, Moreolo GS, et al. Protein-losing enteropathy after fontan operation: Treatment with elementary diet in one case. Paediatr Cardiol 2000; 2I (3):292.

1 12. Kienast W, Haeseler K, Herterich R. Protein-losing enteropathy following the Fontan procedure in a child with intestinal lactase deficiency treated with lactose-free diet. Cardiol Young: 2013;1-3.

1 13. Rothman A, Snyder J. Protein-losing enteropathy following the Fontan operation: Resolution with prednisone therapy. Am Heart J 1991; I 2 I (2 Pt 1):618-619.

114. Zellers TM, Brown K. Protein-losing enteropathy after the modified fontan operation: Oral prednisone treatment with biopsy and laboratory proved improvement. Paediatr Cardiol 1996;17(2):1 15-117.

1 15. Hoashi T, Ichikawa H, Ueno T, et al. Steroid pulse therapy for protein-losing enteropathy after the Fontan operation. Congenit Heart Dis 2009;4(4):284-287.

1 16. Thacker D, Patel A, Dodds K, et al. Use of oral budesonide in the management of protein-losing enteropathy after the Fontan operation. Ann Thorac Surg 2010;89(3):837-842

1 17. Donnelly JP, Rosenthal A, Castle VP, et al. Reversal of protein-losing enteropathy with heparin therapy in 3 patients with univentricular hearts and Fontan palliation. J Paediatr 1997; 130(3):474-478.

I 18. Kelly AM, Feldt RH, Driscoll DJ, et al. Use of heparin in the treatment of proteinlosing enteropathy after fontan operation for complex congenital heart disease. Mayo Clin Proc 1998;73(8):777-779.

1 19. Facchini M, Guldenschuh I, Turina J, et al. Resolution of protein-losing enteropathy with standard high molecular heparin and urokinase after Fontan repair in a patient with tricuspid atresia. J Cardiovasc Surg (Torino) 2000;4 I (4):567-570.

120. Tsuzuki T, Okada H, Takenaka R, et al. Reversal of protein-losing enteropathy with heparin therapy in an adult patient with congenital heart disease. Digestion 2006:74(3-4):206-207.

121. Bhagirath KM, Tam JW. Resolution of protein-losing enteropathy with low molecular weight heparin in an adult patient with Fontan palliation. Ann Thorac Surg 2007;84(6):2110-2112

122. Ryerson L, Goldberg C, Rosenthal A, et al. Usefulness of heparin therapy in protein-losing enteropathy associated with single ventricle palliation. Am J Cardiol 2008; I 0 I (2):248-25 I.

123. Liu M, Liu L, Zhou HM. Reversal of protein-losing enteropathy with heparin therapy in a patient after Fontan operation. Zhonghua Er Ke Za Zhi 2009; 47(1):76-77

124. Takeda M, Shimada M, Sekiguchi A, et al. Long-term results of the fenestrated Fontan operation. Progress of patients with patent fenestrations. Jpn J Thorac Cardiovasc Surg 1999:47(9):432-439

125. Tofeig M, Walsh KP, Chan C, et al. Occlusion of Fontan fenestrations using the Amplatzer septal occluder. Heart 1998;79(4):368-370

126. Marini D, Boudjemline Y, Agnoletti G. Closure of extracardiac Fontan fenestration by using the covered Cheatham Platinum stent. Catheter Cardiovasc Interv 2007;69(7): 1002-1006

127. Jeong SI, Huh J, Lee HJ, et al. Closure of conduit fenestration after extracardiac Fontan procedure using Amplatzer vascular plug: Comparison with detachable coil. Paediatr Cardiol 20 I0;31 ( I):44-49

128. Amin Z, Danford DA, Pedra CA. A new Amplatzer device to maintain patency of Fontan fenestrations and atrial septal defects. Catheter Cardiovasc Interv 2002;57(2):246-25।.

129. Boshoff DE, Brown SC, Degiovanni J, et al. Percutaneous management of a Fontan fenestration: In search for the ideal restriction-occlusion device. Catheter Cardiovasc Interv 2010;75(1):60-65.

130. Crowley DI, Donnelly JP. Use of Amplatzer occlusion devices to occlude Fontan baffle leaks during fenestration closure procedures. Catheter Cardiovasc Interv 2008;7I (2):244-249. 
131. Andrews RE, Tulloh RM, Anderson DR. Coil occlusion of systemic venous collaterals in hypoplastic left heart syndrome. Heart 2002;88(2): 167-169.

132. Shah MJ, Nehgme R, Carboni M, et al. Endocardial atrial pacing lead implantation and midterm follow-up in young patients with sinus node dysfunction after the fontan procedure. Pacing Clin Electrophysiol 2004;27(7):949-954.

133. Takahashi K, Cecchin F, Fortescue E, et al. Permanent atrial pacing lead implant route after Fontan operation. Pacing Clin Electrophysiol 2009;32(6):779-785.

134. Cohen MI, Vetter VL, Wernovsky G, et al. Epicardial pacemaker implantation and follow-up in patients with a single ventricle after the Fontan operation. J Thorac Cardiovasc Surg 200 I; I I (4):804-8 I I.

135. Heinemann MK, Gass M, Breuer J, et al. DDD pacemaker implantation after Fontan-type operations. Pacing Clin Electrophysiol 2003;26(I Pt2):492-495.

136. Rosenthal E, Qureshi SA, Crick JC. Successful long-term ventricular pacing via the coronary sinus after the Fontan operation. Pacing Clin Electrophysiol 1995; | 8( I I):2103-2105.

137. Bacha EA, Zimmerman FJ, Mor-Avi V, et al. Ventricular resynchronisation by multisite pacing improves myocardial performance in the postoperative singleventricle patient. Ann Thorac Surg 2004;78(5): 1678-1683.

138. Lopez JA. Transvenous right atrial and left ventricular pacing after the Fontan operation: Long-term haemodynamic and electrophysiologic benefit of early atrioventricular resynchronisation. Tex Heart Inst J 2007;34( I ):98- I 01 .

139. Estner $\mathrm{HL}$, Kolb C, Schmitt C, et al. Long-term transvenous AV-sequential pacing in a failing atriopulmonary Fontan patient. Int J Cardiol 2008; I 27(2):e93-95.

140. Rosenthal E, Cook A. Pacing lead adhesions after long-term ventricular pacing via the coronary sinus. Pacing Clin Electrophysiol 1999;22(12): 1846-1848.

141. Weinstein S, Cua C, Chan D, et al. Outcome of symptomatic patients undergoing extracardiac Fontan conversion and cryoablation. J Thorac Cardiovasc Surg 2003; 1 26(2):529-536.

142. Kim WH, Lim HG, Lee JR, et al. Fontan conversion with arrhythmia surgery. Eur J Cardiothorac Surg 200527(2):250-257.

143. Ghaferi AA, Hutchins GM. Progression of liver pathology in patients undergoing the Fontan procedure: Chronic passive congestion, cardiac cirrhosis, hepatic adenoma, and hepatocellular carcinoma. J Thorac Cardiovasc Surg 2005; 129(6): 1348-1352.

144. Saliba T, Dorkhom S, O'Reilly EM, et al. Hepatocellular carcinoma in two patients with cardiac cirrhosis. Eur J Gastroenterol Hepatol 2010;22(7):889-891.

145. Asrani SK, Warnes CA, Kamath PS. Hepatocellular carcinoma after the Fontan procedure. N Engl J Med 20।3;368(| 8): I756-1757.

146. Ginde S, Hohenwalter MD, Foley WD, et al. Noninvasive assessment of liver fibrosis in adult patients following the Fontan procedure. Congenit Heart Dis 2012;7(3):235-242.

147. Bulut OP, Romero R, Mahle WT, et al. Magnetic resonance imaging identifies unsuspected liver abnormalities in patients after the Fontan procedure. J Paediatr 2013;163(1):201-206.

148. Serai SD, Wallihan DB, Venkatesh SK, et al. Magnetic resonance elastography of the liver in patients status-post Fontan procedure: Feasibility and preliminary results. Congenit Heart Dis 2013.

149. D'Udekem Y, Xu MY, Galati JC, et al. Predictors of survival after single-ventricle palliation: The impact of right ventricular dominance. J Am Coll Cardiol 2012; 59(13): | | 78-1 | 85

150. Mavroudis C, Backer CL, Deal BJ, et al. Total cavopulmonary conversion and maze procedure for patients with failure of the Fontan operation. J Thorac Cardiovasc Surg 200 I; 122(5):863-871.

151. Mavroudis C, Deal BJ, Backer CL. The beneficial effects of total cavopulmonary conversion and arrhythmia surgery for the failed Fontan. Semin Thorac Cardiovasc Surg Paediatr Card Surg Annu 2002;5: I 2-24.

152. Marcelletti CF, Hanley FL, Mavroudis C, et al. Revision of previous Fontan connections to total extracardiac cavopulmonary anastomosis: A multicenter experience. J Thorac Cardiovasc Surg 2000; 1 19(2):340-346.
153. Hasan A, Au J, Hamilton JR, et al. Orthotopic heart transplantation for congenital heart disease. Technical considerations. Eur J Cardiothorac Surg 1993;7(2):65-70.

154. Carey JA, Hamilton JR, Hilton C], et al. Orthotopic cardiac transplantation for the failing Fontan circulation. Eur J Cardiothorac Surg 1998;14(1):7-13; discussion 13-14.

155. Michielon G, Parisi F, Di Carlo D, et al. Orthotopic heart transplantation for failing single ventricle physiology. Eur J Cardiothorac Surg 2003;24(4): 502-5I0; discussion 510.

156. Gamba A, Merlo M, Fiocchi R, et al. Heart transplantation in patients with previous Fontan operations. J Thorac Cardiovasc Surg 2004; 127 (2):555-562.

157. Backer CL, Russell HM, Pahl E, et al. Heart transplantation for the failing Fontan. Ann Thorac Surg 2013;96(4): 1413-1419.

158. Griffiths ER, Kaza AK, Wyler von Ballmoos MC, et al. Evaluating failing Fontans for heart transplantation: Predictors of death. Ann Thorac Surg 2009;88(2):558-563; discussion 563-554.

159. Michielon G, Carotti A, Pongiglione G, et al. Orthotopic heart transplantation in patients with univentricular physiology. Curr Cardiol Rev 201 1;7(2):85-91.

160. Haggerty CM, Fynn-Thompson F, McElhinney DB, et al.Experimental and numeric investigation of Impella pumps as cavopulmonary assistance for a failing Fontan. J Thorac Cardiovasc Surg 2012;144(3):563-569.

161. Throckmorton AL, Lopez-Isaza S, Moskowitz W. Dual-pump support in the inferior and superior vena cavae of a patient-specific Fontan physiology. Artif Organs 2013;37(6):513-522.

162. Riemer RK, Amir G, Reichenbach SH, et al. Mechanical support of total cavopulmonary connection with an axial flow pump. J Thorac Cardiovasc Surg 2005; 130(2):351-354.

163. Tsuda S, Sasaki T, Maeda K, et al. Recovery during mid-term mechanical support of fontan circulation in sheep. Asaio J 2009;55(4):406-4I I.

164. Boni L, Sasaki T, Ferrier WT, et al. Challenges in longer-term mechanical support of fontan circulation in sheep. Asaio J 20 I2;58(I):60-64. 